\title{
Sedimentary feature on Borsog Bay, eastern shore of Lake Khuvsgul in Northern Mongolia
}

\author{
ALEKSANDER ORKHONSELENGE $^{1}$, K. KASHIWAYA ${ }^{2}$ \\ ${ }^{1}$ Institute of Geography, Mongolian Academy of Sciences, Mongolia \\ ${ }^{2}$ Institute of Nature \& Environmental Technology, Kanazawa University, Japan
}

\begin{abstract}
Sedimentary feature on Borsog Bay, eastern shore of Lake Khuvsgul in Northern Mongolia. This study reports on the sedimentary characteristics of Lake Khuvsgul which is located at the southern end of the Baikal Rift System within the continental interior of East Eurasia. With an elevation of $1645 \mathrm{~m}$ a.s.l., it has a climate that is mainly controlled by the Siberian-Mongolian high pressure system and the westerly wind systems from the Atlantic Ocean. Lake Khuvsgul, Mongolia's second largest lake by surface area $\left(2760 \mathrm{~km}^{2}\right)$, is the country's deepest fresh water lake with a bottom that is only $262 \mathrm{~m}$ a.s.l. Fed by 96 rivers and streams, it is drained by the Eg River which, after joining the Selenge River, flows into Lake Baikal. Analysis of a $12.3 \mathrm{~m}$ core from Borsog Bay near the eastern shore of the lake indicates a sedimentation rate of about $0.08 \mathrm{~cm} / \mathrm{a}$. It is believed that this relatively high sedimentation rate is due to the large sedimentary input from River Borsog and the variability of the turbidity currents at depths shallower than $9 \mathrm{~m}$. It further suggests that the large sedimentation rate may be correlated with the annual and seasonal variations in the dominant westerly wind system over the Siberian Plateau. Such variations have resulted in a lowering of lake level and impacted the rate of erosion within the river's catchment area and therefore the sediment input to the lake. Because this is a preliminary report, further research into the sedimentary dynamics within Lake Khuvsgul and the role played in those dynamics by the climatic variability over Mongolia and Central Asia is planned.
\end{abstract}

Key words: Lacustrine sedimentation, Hydro-geomorphic evolution, Lake Khuvsgul, Mongolia.

\section{INTRODUCTION}

Mongolia can be one of the terrestrial scientific views for the paleo-, current and future environmental studies including climatic changes and continental evolution in Eastern Eurasia and Asia as a specific feature of its location lying in the continental interior of the Eurasia, separated from the ocean. On the other hand, landscapes in Mongolia cannot be regarded only at the country, local level, as a mirror to see the long-term and short-term environmental processes and landform evolution under the climatic forces as a dry air circulation, but also in the Eurasia, regional level. It is very hopeful for the lacustrine records in Mongolia which include the historic environmental changes on the Eurasia during the geologic chronologies have exposed terrestrial evolutions so far. Mongolia is located in transition zone between great Siberian taiga and Central Asian desert on the Eurasian continent under the severe terrestrial climate, which is characterized by Siberian cold air circulation in winter and Central Asian dry air circulation in summer. It has a long, very cold winter $\left(-20.2^{\circ} \mathrm{C}\right)$ and a short, 
hot summer $\left(17.5^{\circ} \mathrm{C}\right)$, with large annual, seasonal and diurnal temperature variations, 250 sunny days a year, average annual rainfall of $200-220 \mathrm{~mm}$ without influence of Asian monsoon (UNEP, 2008). Due to its location distanced from marine or other moisture sources, the prevailing westerly winds arrives as dry in Mongolia without moisture which was already lost in subtropical areas.

In Mongolia, lacustrine sedimentation has been relatively little recorded today. A record on annually laminated lake sediments from Lake Khuvsgul, a mountain lake in the northern part of Mongolia, that directly registers environmental change, can be a high resolution archive for a reconstruction of paleoenvironmental changes and for consideration lacustrine sedimentation induced by climatic-hydraulic factors. It has been remarkably confirmed as a very unique region for reconstructing the paleoclimatic and paleoenvironmental changes in the continental interior of East Eurasia (Kuzmin et al. 2000; Krivonogov et al. 2003; Prokopenko et al. 2005; Goulden et al. 2007). However, to reveal the lacustrine sedimentation, a high-resolution record of the hydro-geomorphic evolutions is needed. For the purpose, in this paper, a high resolution proxy record in the stratification of lacustrine sediments from Borsog Bay of Lake Khuvsgul is presented. It supports the discussion on the Holocene climatic variability which addresses some of the climate-induced environmental changes in the northern part of Mongolia. This study attempts to provide the possibilities and perspectives for reviewing hydro-geomorphic evolution resulting lacustrine sedimentation and determining trend of the Holocene climatic variations and environmental changes in northern Mongolia.

\section{SITE DESCRIPTION}

Lake Khuvsgul (5057'19" N, $100^{\circ} 21^{\prime} 32^{\prime \prime} \mathrm{E}$ ) is located at an elevation of $1645 \mathrm{~m}$ a.s.l in the north of Mongolia near the border to Russia, in the south of the Eastern Sayan Mountain Range elevated at $3000 \mathrm{~m}$ a.s.l in the southern end of the Baikal Rift System, surrounded by high mountain chains that are blocking wet winds (Fig. 1). Lake Khuvsgul is an ultra-oligotrophic freshwater (Edlund et al. 2001), deepest lake (by volume of $383.3 \mathrm{~m}^{3}$ ) in Mongolia, with at the maximum depth of $262.4 \mathrm{~m}, 136 \mathrm{~km}$ length, $36.5 \mathrm{~km}$ maximum breadth and surface area of $2760 \mathrm{sq}$. kms. It is fed by nearly ninety six inflowing streams and rivers, and is drained by an outflow of River Eg, which joins the River Selenge along its eventual path to Lake Baikal. Borsog Bay, sampling point is one of the six parallel catchments entering Lake Khuvsgul along its eastern shore. The lake basin is a transition zone between Central Asian Steppe and Siberian Taiga forest (Larix sibirica), and occupies the southern fringe of the Siberian continuous permafrost zones. The catchment area of Borsog Bay is about $69 \mathrm{~km}^{2}$ with a depth of $9.1 \mathrm{~m}$ (Goulden et al. 2007). The surface geology of the bay consists of Cenozoic volcanic deposits.

Climate in Khuvsgul region is largely controlled by the Siberian-Mongolian high atmospheric pressure zone, along with westerly systems linked to the North Atlantic. In winter time, the Siberian anticyclone results in prolonged cold and 


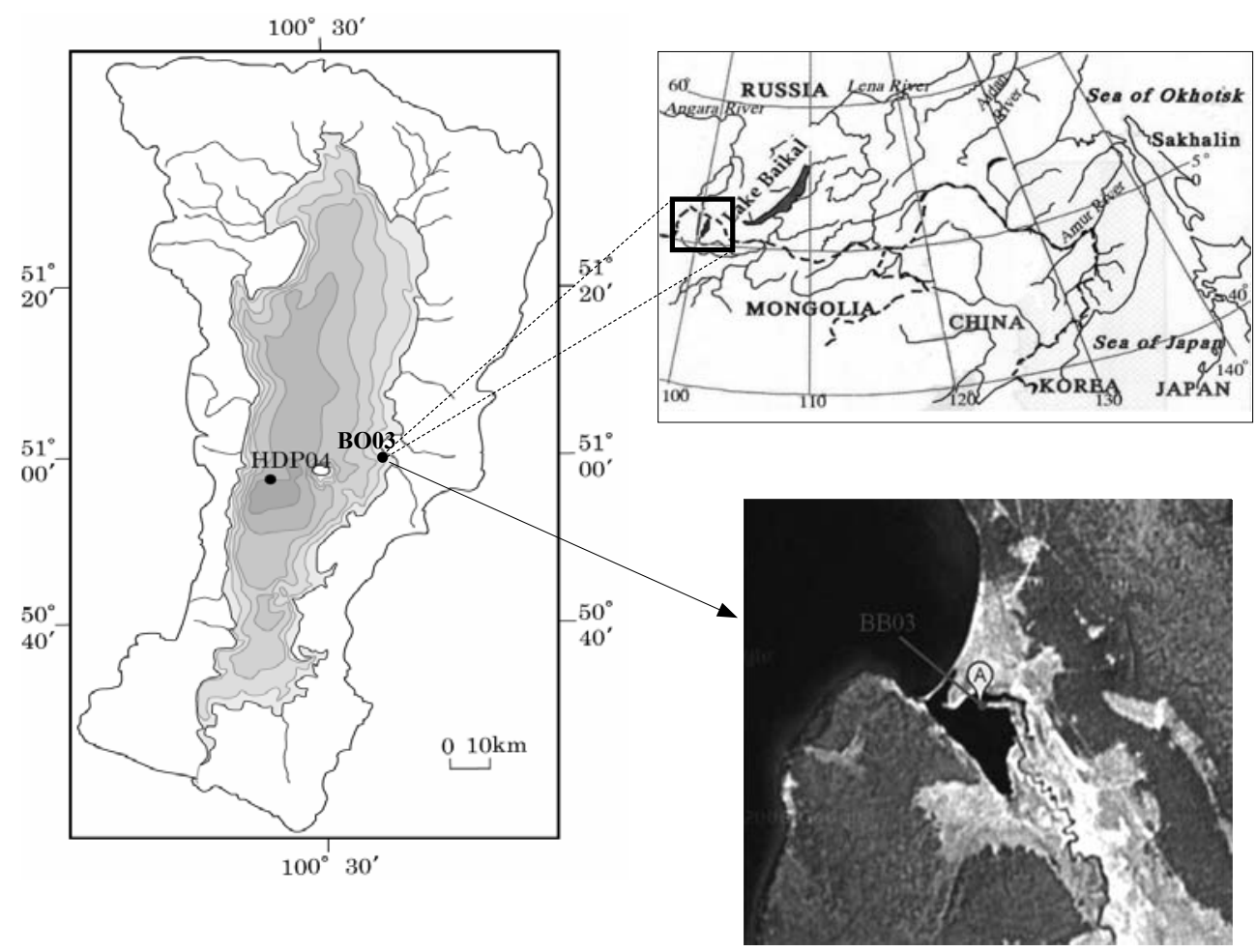

FIGURE 1. Topography of the Lake Khuvsgul catchment

windless weather with little snow. In summer time, dominating western and northwestern cyclones in Central Asia bring warm and moist temperate air masses in the mountains, and dry mass on the plains. Lake Khuvsgul basin has a harsh continental climate with average air temperatures of $12^{\circ} \mathrm{C}$ in July and $-21^{\circ} \mathrm{C}$ in January, varying the mean annual precipitation of $300-350 \mathrm{~mm}$ (Myagmarjav and Davaa 1999), which increases to $550 \mathrm{~mm}$ in the high mountains, because the Sayan Mountain Ranges prevent the northwestern humid airflow from reaching Khuvsgul depression.

\section{MATERIALS AND METHODS}

\section{Coring}

In order to review Holocene climatic variability in northern Mongolia, $12.3 \mathrm{~m}$ length core sediments named by BB03 were taken from Borsog Bay $\left(50^{\circ} 59^{\prime} 09.5^{\prime \prime} \mathrm{N}, 100^{\circ} 42^{\prime} 40.7^{\prime \prime} \mathrm{E}\right)$ on the eastern shore of Lake Khuvsgul in 2003 (Fig. 1). The BB03 core sediments were collected by a core sampler with a 200 $\mathrm{cm}$ long plastic container, which was cut in two parts near its middle section and packed as separate 14 lots. The core was sliced into $1.0 \mathrm{~cm}$ intervals from the top. Hydro-geomorphic features induced by 
climatic variability in the Borsog Bay were reanalyzed by physic-chemical properties and diatom productivity in the littoral sediments.

\section{Analysis of physical, chemical and biological properties}

1233 samples were used for physical and chemical analyses for the samples. The physical and chemical parameters analyzed here are water content, grain density, mineral matter, organic matter, whole grain size, mineral grain size and biogenic silica content.

The analysis of the biogenic silica follows Mortlock and Froelich (1989). Samples of $50 \mathrm{mg}$ were dried at $77^{\circ} \mathrm{C}$ for over 21 hours. Elimination of organic matter was done by hydrogen pyroxide $\left(\mathrm{H}_{2} \mathrm{O}_{2}\right)$ of $10 \% . \mathrm{CaCO}_{3}$ in the sediment was eliminated by $1 \mathrm{~N}$ hydrochloric acid $(\mathrm{HCl})$. Coloring of biogenic silica (biogenic opal) was done by $4 \mathrm{~N} \mathrm{HCl}$ of $0.1 \mathrm{ml}, 6 \mathrm{~N} \mathrm{H}_{2} \mathrm{SO}_{4}$ of $0.2 \mathrm{ml}$ and hexaammonium heptamolybdate tetrahydrate of $0.4 \mathrm{ml}$. Solution of biogenic silica coloring was measured by light-absorption, and dissolved silica in the extractions is measured at wave length of $420 \mathrm{~nm}$ using quartz cells at spectrophotometer. In the result of this analysis, mineral fraction, organic matter, calcium carbonate and biogenic silica are determined.

Grain size was measured for whole sediment and mineral fraction with SALD-2200 laser diffraction particle size analyzer. Firstly, dispersant (Na.H.M.P) was added to samples in a beaker about $30 \mathrm{cc}$ and the beaker was put into ultrasonic cleaner for the samples for 5 minutes. Secondly, measurement was done at flow velocity of six with sensor of laser in a square of $x$ axis and $y$ axis. A set of discharge-nozzle with the discharge-tank should be confirmed for water discharge. The dispersant is poured into SALD to flow, and the samples are poured in SALD with mixing round. Grain size analysis is completed after about one minute from pouring the sample. A calculation of distribution of grain sizes was done on Wing-1 program.

Grain density for sediments in the BB03 core was measured with the AccuPyc1330 of Micrometrics using helium gas. Volume of the helium gas was filled into the gap of sample (particle). The volume of the samples was calculated from volume of chamber and minus. Weight of samples was measured with balance and inputted to the AccuPyc 1330 when the samples are set in the chamber whose volumes are known to the machine display. Finally, the grain density was calculated from the volume and the weight of samples.

\section{Radiocarbon dating and chronology}

Chronology of the $12.3 \mathrm{~m}$ length sediment was established by ${ }^{14} \mathrm{C}$ dates (Tab. 1). Radiocarbon dating $\left({ }^{14} \mathrm{C}\right.$ age $\left.\mathrm{BP}\right)$ for BB03 core was performed with almost $1 \mathrm{~m}$ depth interval by accelerator mass spectrometer (AMS) at Chronological Center of Nagoya University in Japan. The radiocarbon dating was analyzed on total organic carbon (TOC) and wood fragment which was found at $637 \mathrm{~cm}$ depth, and converted into calendar age "cal yr BP". Calibration of dates was performed using weighed averages of over $90 \%(2 \sigma)$ ranges in CALIB 4.1 program with the calibration date set 
TABLE 1. Date of BB03 core sediment

\begin{tabular}{|r|c|c|c|c|c|c|c|}
\hline $\begin{array}{c}\text { Depth } \\
{[\mathrm{cm}]}\end{array}$ & $\begin{array}{c}14 \mathrm{C} \text { age } \\
{[\mathrm{yr} \text { BP }]}\end{array}$ & $\begin{array}{c}\text { Error } \\
{[\mathrm{yr} \text { BP }]}\end{array}$ & Material & $\begin{array}{c}\text { Tentative } \\
\text { corrected 14C age } \\
{[\mathrm{yr} \text { BP }]}\end{array}$ & $\begin{array}{c}\text { Tentative } \\
\text { cal. age } \\
\text { [yr calBP }]\end{array}$ & $\begin{array}{c}\text { Estimated } \\
\text { Max }\end{array}$ & $\begin{array}{c}\text { Estimated } \\
\text { Min }\end{array}$ \\
\hline 2 & 2555 & 31 & TOC & 555 & 542 & 564 & 519 \\
\hline 5 & 3025 & 36 & TOC & 1025 & 954 & 1005 & 903 \\
\hline 87 & 3013 & 33 & TOC & 1013 & 941 & 982 & 900 \\
\hline 127 & 2759 & 32 & TOC & 759 & 700 & 733 & 666 \\
\hline 177 & 2749 & 32 & TOC & 749 & 696 & 731 & 661 \\
\hline 300 & 3826 & 35 & TOC & 1826 & 1780 & 1865 & 1694 \\
\hline 400 & 4706 & 36 & TOC & 2706 & 2810 & 2867 & 2753 \\
\hline 504 & 5959 & 37 & TOC & 3959 & 4408 & 4522 & 4293 \\
\hline 581 & 5935 & 35 & TOC & 3935 & 4347 & 4445 & 4248 \\
\hline 638 & 4079 & 29 & Wood & 4079 & 4581 & 4647 & 4514 \\
\hline 700 & 5869 & 39 & TOC & 3869 & 4320 & 4416 & 4223 \\
\hline 802 & 6115 & 37 & TOC & 4115 & 4627 & 4729 & 4524 \\
\hline 900 & 7042 & 38 & TOC & 5042 & 5807 & 5904 & 5709 \\
\hline 981 & 8214 & 42 & TOC & 6214 & 7127 & 7249 & 7004 \\
\hline 1000 & 7879 & 40 & TOC & 5879 & 6711 & 6794 & 6628 \\
\hline 1061 & 7969 & 43 & TOC & 5969 & 6793 & 6909 & 6676 \\
\hline 1100 & 8328 & 42 & TOC & 6328 & 7247 & 7329 & 7165 \\
\hline 1200 & 8984 & 43 & TOC & 6984 & 7791 & 7879 & 7702 \\
\hline
\end{tabular}

of IntCal04 (Reimer et al. 2004). The reservoir effect for Borsog Bay, littoral part in Lake Khuvsgul seems longer than the pelagic parts. Because of that, the Borsog Bay is a lacustrine fringe, where gets lots of terrigenous organic soil input, and the terrigenous organic soil has older age. Tentative correction was done by subtraction of 2000 from TOC age (Tab. 1).

\section{RESULTS}

\section{Sedimentation rate}

The age-depth model for eastern littoral part, Borsog Bay of Lake Khuvsgul suggests that the Borsog Bay may have been already under lake water in the early Holocene (Tab. 1). Two parts of the core sequence where there are relatively constant radiocarbon ages are found in the sediments from Borsog Bay (Fig. 2), and they correspond to the middle part during ca 5.2-3.8 cal kyr BP and latter part during ca 800-600 cal yr BP.

Sedimentation behavior in Lake Khuvsgul can be clearly distinguished on the basis of fluctuations on the physicchemical properties in the BB03 core sediment, certain suggestive climatic variability reflecting the prevailing environmental conditions (Fig. 2). The 12.3 $\mathrm{m}$ thick sediment sequence for the BB03 core estimates the average sedimentation rate of about $0.08 \mathrm{~cm} / \mathrm{yr}$ on Borsog Bay, eastern littoral part of Lake Khuvsgul. This higher sedimentation rate on Borsog Bay as compared with those on the pelagic parts in Lake Khuvsgul where the Holocene average rates are 
$4.3 \mathrm{~cm} / \mathrm{kyr}$ and $4.2 \mathrm{~cm} / \mathrm{kyr}$ in cores X104 and X106, respectively (Nara et al. 2005); $0.4 \mathrm{~cm} / \mathrm{kyr}$ and $1.4 \mathrm{~cm} / \mathrm{kyr}$ in cores X4-2 and X8-2 during the late Holocene, respectively (Nakamura et al. 2003), may be attributed to its location on littoral part, which lies under influence of transportation of the terrigenous sediments along the fluvial drainage basin of River Borsog toward the lake. On the other hand, the sedimentary behavior on Borsog Bay indicates that the quite different environment in shallower lake in the entire Holocene with higher mineralization as compared with sedimentary records with low sedimentation rate for the pelagic sediments in Lake Khuvsgul. Lacustrine sedimentation in Lake Khuvsgul differs distinctive features of hydrologic regime and geomorphologic evolution in lake catchment attempted by regional landscape and climatic changes. In particular, the hydrologic regime resulting in the large sedimentation has been determined by not only an overland flow of melting water due to thawing process of glaciers, but also a base flow due to thawing process of thick permafrost around Khuvsgul region.

\section{Physic-chemical properties of the BB03 core sediment}

Certain climate-induced extreme sedimentations have been apparently determined by fluctuation of physic-chemical properties of the each parameter in the BB03 core sediment (Fig. 2).

Grain size in whole sediments: Whole grain size in the BB03 core sediment ranges from $4.3 \varphi$ to $6.9 \varphi$ in except of the finest and coarsest sediment fractions (Fig. 2a). The finest fraction at about
$7.5 \varphi$ is found in $1028 \mathrm{~cm}$ depth, while the coarsest fractions at about $2.5 \varphi$ and $3.9 \varphi$ are found appeared in $83 \mathrm{~cm}$ depth and $637 \mathrm{~cm}$ depth, respectively (Fig. 2a). Apparently, both peaks of the coarsest fractions in the fluctuation of grain size indicate the certain climatic events, which may show a short-term rapid extreme surface runoff due to melted water discharge induced by thawing of glaciers on Khuvsgul Mountain Range.

Grain size in mineral fraction: Fluctuation of mineral grain size has a similar pattern with fluctuations of the whole grain size, and it ranges between $2.5 \varphi$ and $7.1 \varphi$ (Fig. 2b). Totally, grain sizes in the mineral fractions consist of the fluctuations with depths. The coarsest minerals are at about $2.9 \varphi-2.5 \varphi$ in $81-95 \mathrm{~cm}$ interval, and $3.2 \varphi-3.1 \varphi$ in $601-651 \mathrm{~cm}$ depths, respectively (Fig. 2b), while the finest minerals are at about $7.1 \varphi$ and $6.9 \varphi$ in $215 \mathrm{~cm}$ and $455 \mathrm{~cm}$ depths, respectively. Similarly with fluctuation of grain size in whole sediment, clear fluctuations for the both peaks in the BO03 core show the features on a runoff generation, in particular the activity of much more powerful outflow of water discharge induced by thawing of glaciers, which resulting in large amounts of surface sediments.

Mineral fraction: Mineral fraction is meanly included at about $55.8 \%$ in the BB03 core sediment, and ranges from $20 \%$ to $95 \%$ (Fig. 2c). The largest and lowest amounts of mineral fraction appear at about $94.1 \%$ and $19.5 \%$ at $715 \mathrm{~cm}$ and $225 \mathrm{~cm}$ depths, respectively. Fluctuation of the mineral fraction indicates three peaks which implying extreme large sedimentation due to surface discharge. 


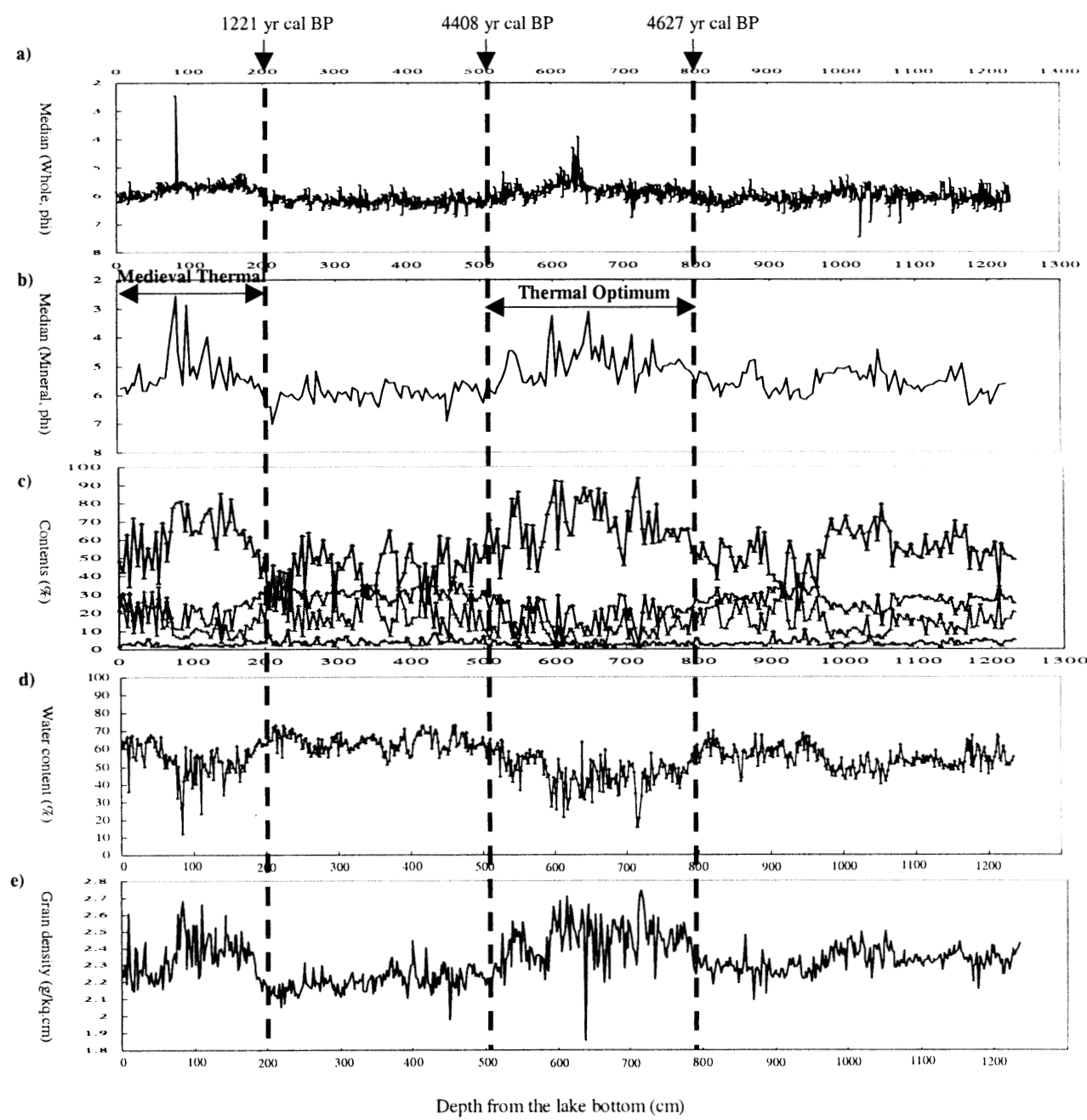

FIGURE 2. Physical properties of short core (BO03); a) Whole grain size, b) Mineral grain size, c) Mineral content (Blue), Organic matter (Pink), Biogenic silica (Green) and $\mathrm{HCl}$ soluble material (Red), d) Water content and e) Grain density

Organic matter: Organic matter is meanly included at about $25.3 \%$ in the BB03 core sediment (Fig. 2c). Abundant preservations of plant fragments are well determined in $83 \mathrm{~cm}$ and $637 \mathrm{~cm}$ depths. The maximum values are contained at about $36.6 \%, 35.8 \%$ and $35.7 \%$ in $461 \mathrm{~cm}$, $471 \mathrm{~cm}$ and $945 \mathrm{~cm}$ depths, respectively. While the minimum values are contained at about $2.9 \%, 4.2 \%$ and $4.4 \%$ in $715 \mathrm{~cm}$, $611 \mathrm{~cm}$ and $601 \mathrm{~cm}$ depths, respectively (Fig. 2c). In general, fluctuation of the organic matter indicates four peaks which imply warm environment in the Borsog Bay.

Biogenic silica: Biogenic silica is meanly contained at about $15.4 \%$ in the BB03 core sediments. The maximum 
biogenic silica appears at $43.8 \% 42.0 \%$ and $40.9 \%$ in $225 \mathrm{~cm}, 295 \mathrm{~cm}$ and $935 \mathrm{~cm}$ depths, respectively (Fig. 2c), whereas the minimum amounts of biogenic silica appear at about $1.21 \%$ and $1.98 \%$ in $715 \mathrm{~cm}$ and $601 \mathrm{~cm}$ depths, respectively. The fluctuation of the biogenic silica reflects the humid and warm environment through the four peaks.

Calcium carbonate: The fluctuation of calcium carbonate indicates a similar pattern with the organic matter and biogenic silica due to estimation by relative value for these parameters. In general, $\mathrm{HCl}$ soluble material ranges from $1.08 \%$ to $10.67 \%$ among the whole depth with maximum values of $10.67 \%, 9.76 \%$ and $8.67 \%$ in $231 \mathrm{~cm}, 901 \mathrm{~cm}$ and $431 \mathrm{~cm}$ depths, respectively (Fig. 2c). The three peaks among the fluctuation describe the cold and dry environment.

Water content: Water content of the BB03 core sediments ranges at 12.1$-73.4 \%$. Maximum water contents of $73.4 \%$ and $73.3 \%$ are found in $213 \mathrm{~cm}$ and $461 \mathrm{~cm}$ depths, respectively (Fig. 2d). The minimum water contents of $12.1 \%$ and $15.7 \%$ are found in $83 \mathrm{~cm}$ and $715 \mathrm{~cm}$ depths, respectively. The four peaks among the fluctuations of water content in the BB03 core sediment indicate humid and warm environments (Fig. 2d).

Grain density: Grain density of the $\mathrm{BB} 03$ core sediments ranges between $1.85 \mathrm{~g} / \mathrm{cm}^{3}$ and $2.74 \mathrm{~g} / \mathrm{cm}^{3}$ (Fig. 2e). The densest sediments at about $2.74 \mathrm{~g} / \mathrm{cm}^{3}$ and $2.71 \mathrm{~g} / \mathrm{cm}^{3}$ are found in $611 \mathrm{~cm}$ and $715 \mathrm{~cm}$ depths, respectively (Fig. 2e), i.e., two peaks are occurred in fluctuation of the grain density. The minimum density at $1.85 \mathrm{~g} / \mathrm{cm}^{3}$ was found in $637 \mathrm{~cm}$ depth due to a presence of wood fragment (Fig. 2e). Dense sediments expressed by two peaks toward the depth of the BB03 core show the extreme surface discharge.

\section{DISCUSSION}

Record of sedimentary stratification in BB03 core from Borsog Bay, littoral part of Lake Khuvsgul shows a specific pattern of lacustrine sedimentation controlled by the short-term extreme surface discharge due to thawing processes of glaciers and permafrost than surface erosion during low-stand lake level and sediment transportation induced by arid air circulation from far distance. The $12.3 \mathrm{~m}$ thick lacustrine sequence for the BB03 core suggests the high sedimentation rates of about $0.08 \mathrm{~cm} / \mathrm{yr}$. BB03 core sediments consist of more coarse fractions and has higher sedimentation rate in comparison with records on the long core sediments from the pelagic parts in Lake Khuvsgul. In pelagic parts of Lake Khuvsgul, the late Holocene sedimentation rates are low as at $0.7 \mathrm{~cm} / \mathrm{kyr}$ in core X3-1 and $1.7 \mathrm{~cm} / \mathrm{kyr}$ in core X2-2 (Nakamura et al. 2003), and as at over $6.2 \mathrm{~cm} / \mathrm{kyr}$ and $6.7 \mathrm{~cm} / \mathrm{kyr}$ in cores 19 and 20, respectively (Prokopenko et al. 2005). The large amounts of coarse grain sizes for whole sediment and mineral fraction show the intensive sedimentations due to the large amounts of melted water discharge induced by thawing of glaciers and permafrost around Khuvsgul region at $940 \mathrm{yr}$ cal BP and $4580 \mathrm{yr}$ cal BP (Fig. 2a, b), i.e., the similar two peaks for fluctuations of the grain sizes in the whole sediments and mineral fractions show a periodic outflow by thawing water resulted from the mountain glaciers around lake catchment. The large sedimentation of the coarsest fractions 
differ a specific hydraulic regime of lake on local level, i.e., the hydraulic regime is mainly controlled by overland flow and baseflow in spring time than surface discharge supported by rainfall in summer time. Additionally, the relative high sedimentation on Borsog Bay is expected to be affection of local turbid through shallower depth of $9.1 \mathrm{~m}$ and of terrigenous sedimentary input via extreme discharge of River Borsog, i.e., as compared with those in pelagic parts, the high sedimentation on Borsog Bay may be related to the littoral location of the Borsog Bay. Apparently, the large sedimentation is indicated by a different agent as compared with sedimentation process resulted from the decrease of lake level due to the abrupt climatic event of the aridity.

The records of the sedimentary stratification from Borsog Bay, littoral part of Lake Khuvsgul suggest the local specific feature on climatically-induced environmental changes throughout the Holocene as compared with the records from pelagic parts in Lake Khuvsgul. Apparently, it is expected that the Borsog Bay has been already covered by lake water by the $7.8 \mathrm{kyr}$ cal BP. It is corresponded with the note by Prokopenko et al (2005) as the Lake Khuvsgul evolved from a lowlevel closed basin lake to an overflowing freshwater lake by the beginning of the Holocene. This hypothesis is apparently supported by the $12.3 \mathrm{~m}$ lacustrine sequence for the core BB03 on Borsog Bay throughout the Holocene, i.e., the lacustrine sedimentation on Borsog Bay reveals the quite different feature due to its littoral location as compared to the records from the pelagic parts in the Lake Khuvsgul during the entire Holocene.

\section{CONCLUSION}

Hydro-geomorphic evolution is considered in Lake Khuvsgul in northern Mongolia through a high-resolution record on lacustrine sedimentation in littoral Borsog Bay. It supports a view on quite abrupt variable Holocene environment induced by climatic change. $12.3 \mathrm{~m}$ lacustrine sequence in Lake Khuvsgul shows a local feature of lacustrine sedimentation resulted from short-term extreme overland flows due to thawing process of glaciers. The frequencies of the Holocene variability occur in continuously periodic patterns, and the some patterns appear to have comprised rapid short-terms. It plausibly responds synchronously to Northern Hemisphere during the Holocene climate changes. However, it is apparently responsible for delay event on regional scale, i.e., it emphasizes the highlighting for the local discrepancy of the Holocene climate based on the site-specific record. The present effort is only a primary high resolution data on lacustrine sedimentation supporting local climatic change within the Holocene in northern Mongolia, consequently, it would be major role to a further, precise study on the landform evolution in lake-catchment system and Holocene climatic changes in Mongolia. Future research will identify the additional aspects of the Holocene climatic changes that are of great interest to the development of a comprehensive view of climate variability within the current interglacial period, and provide precise information regarding the history of lake level changes in Lake Khuvsgul. Consequently, further advances will require more paleoclimate records, notably, 
more precise analysis of the timing of rapid climatic change intervals through long core sediment from Lake Khuvsgul and multiple cores from other lakes in Mongolia.

\section{REFERENCES}

EDLUND M.B., ANDRESEN N.A., SONINKHISHIG N., 2001: Morphology of Oestrupia zachariash and its transfer to Biremis, Diatom Research, Volume 16 (2), p. 295-306.

GOULDEN C.E., SITNIKOVA T., BOLDGIV B., GELHAUS J. (Ed.), 2006: The Geology, Biodiversity and Ecology of Lake Huvsgul (Mongolia). Backhuys Publ., Amsterdam, 501 p.

KRIVONOGOV S.K., BEZRUKOVA V.E., TAKAHARA H., RIEDEL F., 2003: Lake Hovsgol in the Late Pleistocene and Holocene: on-land geological evidence for a change in its level. In: Kashiwaya, K. (Ed.), Long Continental Records from Lake Baikal. Springer-Verlag, Tokyo, pp. 187-206.

KUZMIN M.I., KARABANOV E.B., PROKOPENKO A.A., GELETY V.F., ANTIPIN V.S., WILLIAMS D.F., GVOZDKOV A.N., 2000: Sedimentation processes and new age constraints on rifting stages in Lake Baikal: results of deep-water drilling. International Journal of Earth Sciences 89 (2), 183-192.

MORTLOCK R.A., FROELICH P.N., 1989: A simple method for the rapid determination of biogenic opal in pelagic marine sediments. Deep Sea Research 36, 1415-1426.

NARA F., TANI Y., SOMA M., NARAOKA H., WATANABE T., HORIUCHI K., KAWAI T., ODA T., NAKAMURA T., 2005: Response of phytoplankton productivity to climate change recorded by sedimentary photosynthetic pigments in Lake Hovsgol (Mongolia) for the last 23,000 years. Quaternary International 136, $71-81$

PROKOPENKO A.A., KUZMIN M.I., WILLIAMS D.F., GELETY V.F., KALMYCHKOV G. V., GVOZDKOV A. N., SOLOTCHIN P.A., 2005: Basin-wide sedimentation changes and deglacial lake-level rise in the Hovsgol basin, NW Mongolia. Quaternary International 136, 59-69.
REIMER P.J., BAILLIE M. G.L., BARD E., BAYLISS A., BECK J. W., BERTRAND C., BLACKWELL P.G., BUCK C.E., BURR G., CUTLER K.B., DAMON P E., EDWARDS R.L., FAIRBANKS R.G., FRIEDRICH M., GUILDERSON T.P., HUGHEN K.A., KROMER B., McCORMAC F.G., MANNING S., BRONK RAMSEY C., REIMER R.W., REMMELE S., SOUTHON J.R., STUIVER M., TALAMO S., TAYLOR F.W., van der PLICHT J., WEYHENMEYER C.E., 2004: IntCal04: calibration issue. Radiocarbon 46 (3), 1029-1058.

UNEP, 2008: A report of United Nations Environment Programme.

Streszczenie: Właściwości osadów w Jeziorze Khuvsgul w Pótnocnej Mongolii. W pracy przedstawiono charakterystykę osadów dennych w zatoce Borsog na Jeziorze Khuvsgul w północnej Mongolii. Właściwości fizyczne i chemiczne osadów określono na podstawie próby o miąższości $12,3 \mathrm{~m}$, którą podzielono na 1233 próbki. Datowanie wieku poszczególnych warstw osadów wykonano na podstawie zawartości izotopu węgla ${ }^{14} \mathrm{C}$. Stwierdzono, że osady na głębokości $12 \mathrm{~m}$ pod powierzchnią dna zatoki mają około 7800 lat, a średnie tempo przyrostu miąższości osadów wynosi $0,08 \mathrm{~cm}^{-1} \mathrm{rok}^{-1}$. Na podstawie analizy tempa przyrostu poszczególnych warstw osadu oraz zmienności ich właściwości fizycznych i chemicznych stwierdzono, że występuje duża zgodność przebiegu procesu sedymentacji osadów w zatoce Borsog z lokalnymi zmianami klimatu.

\section{MS. received April 2010}

Authors' address:

\section{A. Orkhonselenge}

Institute of Geography Sukhbaatar-11

210-620 Ulaanbaatar

Mongolia

e-mail: alorsel@gmail.com

\section{K. Kashiwaya}

Institute of Nature \& Environmental Technology,

Kanazawa University, Kanazawa

Japan 